\title{
Proteomic analysis of the metabolic adaptation of the biocontrol agent Pseudozyma flocculosa leading to glycolipid production
}

\author{
Walid Hammami, Florian Chain, Dominique Michaud and Richard R Bélanger*
}

\begin{abstract}
The yeast-like epiphytic fungus Pseudozyma flocculosa is known to antagonize powdery mildew fungi through proliferation on colonies presumably preceded by the release of an antifungal glycolipid (flocculosin). In culture conditions, P. flocculosa can be induced to produce or not flocculosin through manipulation of the culture medium nutrients. In order to characterize and understand the metabolic changes in P. flocculosa linked to glycolipid production, we conducted a 2-DE proteomic analysis and compared the proteomic profile of $P$. flocculosa growing under conditions favoring the development of the fungus (control) or conducive to flocculosin synthesis (stress). A large number of protein spots (771) were detected in protein extracts of the control treatment compared to only 435 matched protein spots in extracts of the stress cultures, which clearly suggests an important metabolic reorganization in slow-growing cells producing flocculosin. From the latter treatment, we were able to identify 21 protein spots that were either specific to the treatment or up-regulated significantly (2-fold increase). All of them were identified based on similarity between predicted ORF of the newly sequenced genome of P. flocculosa with Ustilago maydis'available annotated sequences. These proteins were associated with the carbon and fatty acid metabolism, and also with the filamentous change of the fungus leading to flocculosin production. This first look into the proteome of P. flocculosa suggests that flocculosin synthesis is elicited in response to specific stress or limiting conditions.
\end{abstract}

\section{Introduction}

Pseudozyma flocculosa (Traquair, Shaw, and Jarvis) Boekhout and Traquair, a basidiomycetous yeast originally classified as Sporothrix flocculosa, is a powerful and specific antagonist of powdery mildew fungi whose mode of action appears to be unique among other related Pseudozyma species [1]. It is able to colonize powdery mildew colonies within a few hours following its contact with the pathogen and this ability was preceded and/or facilitated by the release of an antifungal glycolipid. This glycolipid, named flocculosin, was recently isolated and purified from solid cultures of $P$. flocculosa [2]. Extracellular glycolipids are produced by a large variety of microorganisms and may serve different purposes to confer fitness advantages. Interestingly, the structure of flocculosin is closely related to the cellobiose lipid, ustilagic acid, produced by the plant pathogen Ustilago maydis [2]

\footnotetext{
* Correspondence: richard.belanger@fsaa.ulaval.ca

${ }^{1}$ Département de Phytologie, Centre de recherche en horticulture, Université Laval, Québec G1V 0A6, Canada
}

In a previous study, the absence of growth factors contained in yeast extract, combined with high carbon availability were described as stress conditions inducing the production of flocculosin in P. flocculosa cultures [3]. However, it is unclear how these conditions relate to the antagonistic behavior of the fungus in nature.

In spite of recent technical advances in molecular biology, the molecular basis of metabolic changes of P. flocculosa under stress condition is poorly understood because of the limited knowledge about the genetics of Pseudozyma spp. in general and of P. flocculosa in particular. Recently, Marchand et al. [4] isolated and studied the expression of a putative homolog of a cyp1 gene involved in the biosynthesis of ustilagic acid in U. maydis [5]. They showed a direct correlation between cyp1 expression and flocculosin production in stressed cultures of $P$. flocculosa but did not observe major differences in cyp1 expression when the fungus was developing on healthy or powderymildew infected leaves. These findings offered a relative appreciation of gene expression without information on 
the post-translational modifications or the relative concentration of the gene products (protein). Given that no strong correlation necessarily exists between the amount of a given protein and its transcripts [6], an in-depth analysis of the $P$. flocculosa proteome under comparative conditions would provide more precise information and a better understanding of the global cellular response of $P$. flocculosa that can trigger its biocontrol activity.

The most common implementation of proteome analysis is the separation of proteins by two-dimensional gel electrophoresis (2-DE) and their identification by peptide analysis with mass spectrometry (MS) analytical methods. Upon encountering new growth conditions, the microorganism under study will alter its protein synthesis in order to adapt to the new environment. Thus, by applying proteomic techniques such as 2-DE, different protein patterns from the same organism exposed to different environments can be compared. For example, Böhmer et al. [7] were able to study the dimorphic transition from budding to filamentous growth in $U$. maydis by comparing the proteome maps of the two forms by 2-DE. They thus identified 13 protein spots that were significantly enhanced during filamentous growth induced by the bW2/bE1-heterodimer. A similar approach was used to characterize virulence factors of Botrytis cinerea [8].

The objective of this study was to characterize the metabolic changes in P. flocculosa under two specific conditions inducing morphological characteristics conducive or not to flocculosin synthesis. For this purpose, we conducted a comparative analysis of the protein profile of each condition using a 2-DE approach. Taking advantage of the recent sequencing of the P. flocculosa genome, proteins of interest were matched with predicted ORFs in $P$. flocculosa and identified with a high level of confidence based on similarity to entries in available genome databanks including that of $U$. maydis.

\section{Materials and methods Fungal material}

P. flocculosa (DAOM 196992) was used throughout this study. Stock cultures consisted of conidia lyophilized in maltose $(20 \%)$ and kept at $-80^{\circ} \mathrm{C}$ as aliquots of ca. $1 \times 10^{6}$ cells. Mother cultures were obtained by inoculating 100 $\mathrm{ml}$ of YMPD medium (yeast extract $3 \mathrm{~g} / \mathrm{l}$, malt extract 3 $\mathrm{g} / \mathrm{l}$, peptone water $5 \mathrm{~g} / \mathrm{l}$ and dextrose $10 \mathrm{~g} / \mathrm{l}$ ) in a $500 \mathrm{ml}$ baffled flask with one bottle of lyophilized cultures previously hydrated with $3 \mathrm{ml}$ of sterile water. All culture media ingredients were supplied by Difco (BD Biosciences, Mississauga, Ontario, Canada). Seed cultures consisting of sporidia, were prepared by inoculating $100 \mathrm{ml}$ of YMPD medium with $5 \mathrm{ml}$ of a 3-day-old mother culture. The seed cultures were maintained on a rotary shaker set at $150 \mathrm{rpm}$ at room temperature and were transferred into a fresh medium every three days for a maximum period of 30 days.

\section{Culture conditions}

Two specific culture conditions for $P$. flocculosa as defined by Hammami et al. [3] were used in this study: one favoring morphological characteristics leading to sporidia production (control), and one favoring limited germination of the spores and mycelial fragments with associated production of flocculosin (stress). Briefly, $5 \mathrm{ml}$ of the seed culture were used to inoculate $100 \mathrm{ml}$ of $\mathrm{YMPD}_{0.5}$ medium (yeast extract $3 \mathrm{~g} / \mathrm{l}$, malt extract $3 \mathrm{~g} / \mathrm{l}$, peptone water $2.5 \mathrm{~g} / \mathrm{l}$ and dextrose $5 \mathrm{~g} / \mathrm{l}$ ) in a $500-\mathrm{ml} \mathrm{baf-}$ fled flask. To stress the cells into producing flocculosin, a $10-\mathrm{ml}$ sucrose solution $(10 \%)(\mathrm{w} / \mathrm{v})$ was added to the medium after $72 \mathrm{~h}$, and this process was repeated $24 \mathrm{~h}$ later. For the control conditions, no amendments were made to the medium for the duration of the culture. After $120 \mathrm{~h}$, the cell biomass was collected by filtration and used for protein extraction.

\section{Protein extraction}

Fungal cells from both control and stress conditions were ground to a fine powder in liquid nitrogen using a cooled mortar. The extraction procedure consisted of protein solubilization with phosphate buffer followed by protein precipitation with trichloroacetic acid (TCA)/acetone (phosphate-TCA-acetone). The cell powder ( $4 \mathrm{~g}$ ) was suspended in $10 \mathrm{ml}$ of $10 \mathrm{mM}$ potassium-phosphate buffer $(\mathrm{pH}$ 7.4) containing $0.07 \% \mathrm{w} / \mathrm{v}$ dithiothreitol (DTT) (Sigma-Aldrich, St. Louis, MO) and $200 \mu$ of protease inhibitor cocktail for fungi and yeasts (Sigma, St. Louis, MO). The mixture was stirred at $4^{\circ} \mathrm{C}$ for $2 \mathrm{~h}$ and the extract clarified by centrifugation $(15 \mathrm{~min}, 20000 \mathrm{~g})$. The supernatant was recovered and the proteins were precipitated by the addition of an equal volume of $10 \% \mathrm{w} / \mathrm{v}$ TCA in acetone containing $0.07 \% \mathrm{w} / \mathrm{v}$ DTT. The proteins were allowed to precipitate for $1 \mathrm{~h}$ at $-20 \mathrm{C}$ and the protein pellet recovered after centrifugation (15 $\mathrm{min}, 15000 \mathrm{~g}$ ) was washed twice with acetone containing $0.07 \% \mathrm{w} / \mathrm{v}$ DTT. The pellet was then solubilized in an electrophoretic sample buffer consisting of $8 \mathrm{M}$ urea (Sigma-Aldrich) containing $2 \%$ (w/v) CHAPS, $0.5 \%$ (v/v) IPG buffer $\mathrm{pH} 3$ 10 , and $60 \mathrm{mM}$ DTT. Protein concentration in the samples was determined using the method of Bradford [9], with ovalbumin as standard protein according to the supplier's recommendation (Bio-Rad, Hercules, Ca). Final sample volumes of each extract were adjusted to normalize the amount of protein per sample to $300 \mu \mathrm{g} / 250 \mu \mathrm{l}$.

\section{2-DE}

For IEF, the samples were diluted in sample buffer containing a few grains of bromophenol blue, to a concentration of $400 \mu \mathrm{g} / 250 \mu \mathrm{l}$. The samples were then loaded on 
immobiline IPG strips $(13 \mathrm{~cm})$ with a linear $\mathrm{pH}$ 3-10 gradient, and resolved using an IPGphor apparatus (Amersham Biosciences, Baie d'Urfé, Québec,). After active rehydration for $12 \mathrm{~h}$, IEF was performed following a voltage step-gradient (100 V for $1 \mathrm{~h}, 500 \mathrm{~V}$ for $1 \mathrm{~h}, 1000 \mathrm{~V}$ for $1 \mathrm{~h}, 5000 \mathrm{~V}$ for $1 \mathrm{~h}$, and $8000 \mathrm{~V}$ to reach $47320 \mathrm{Vh}$ ). Before SDS-PAGE, the IPG strips were equilibrated for $15 \mathrm{~min}$ in a solution containing $6 \mathrm{M}$ urea, $50 \mathrm{mM}$ Tris- $\mathrm{HCl} \mathrm{pH} \mathrm{8.8,}$ $2 \%(\mathrm{w} / \mathrm{v})$ SDS, 30\% (v/v) glycerol, and $60 \mathrm{mM} \mathrm{DTT}$, and then equilibrated for $15 \mathrm{~min}$ in the same solution after substituting DTT with 5\% (v/v) iodoacetamide (SigmaAldrich, St. Louis, MO). The second dimension was carried out on a $1 \mathrm{~mm}$ thick $12 \%(\mathrm{w} / \mathrm{v})$ polyacrylamide gel. The gels were run at constant $30 \mathrm{~mA}$ until the bromophenol blue dye front migrated $2 \mathrm{~cm}$ from the bottom. The proteins were fixed overnight in water containing $10 \%(\mathrm{v} /$ v) acetic acid, $50 \%(\mathrm{v} / \mathrm{v})$ methanol on a rocking platform at low speed. The gels were finally rinsed three times in Milli-Q water and stained with the GelCode blue reagent (Pierce, Rockford, IL) following the manufacturer's instructions. Three replicate gels from individuals exposed to the same experimental conditions were performed to allow for subsequent statistical assessments.

\section{Image analysis and protein identification P. flocculosa genome sequencing}

Genomic DNA was extracted using the Qiagen DNeasy Plant Mini Kit from a 10-ml aliquot of a 3-day-old culture of $P$. flocculosa. Using 454 sequencing Titanium technology (454 Life Sciences Corp), the DNA genome of P. floc- culosa was sequenced at the Genome Quebec Innovation Center (Montréal, QC, Canada). Briefly, 1.4 million reads were generated and $80 \%$ of them were fully assembled into 3410 contigs. Due to the large size of this genome (22 $\mathrm{Mb}$ ), a long paired end sequencing approach was used to arrange the contigs (order/orientation) into 1281 scaffolds. The sequences contained on these scaffolds were used for protein identification based on matches with predicted ORFs and extraction of the corresponding sequences for further analysis (see below).

\section{Protein identification}

The 2-DE gels were digitized and analyzed using the Phoretix 2D Expression software, v. 2005 (NonLinear USA Inc., Durham, NC). Protein spot intensities were normalized using the 'total spot volume' method (i.e., each spot being expressed as a percentage of the total spot volume on that gel) to account for variations in emission levels between images, and a background subtraction was performed following the supplier's recommendations. Detection by gel to gel matching was performed to identify differences among treatments. All matched spots were detected on at least two gels from each set of three gels (replicates). Protein spots for identification were excised from the gels manually, and incubated for $15 \mathrm{~min}$ in $250 \mu \mathrm{l}$ of water/acetonitrile $(1: 1 \mathrm{v} / \mathrm{v})$. After additional washes in acetonitrile and $100 \mathrm{mM} \mathrm{NH}_{4}-\mathrm{HCO}_{3}$, the proteins were reduced with dithiothreitol, alkylated with iodoacetamide, and digested to peptides overnight at $37^{\circ} \mathrm{C}$ with MS grade Trypsin Gold (Promega Corpora-
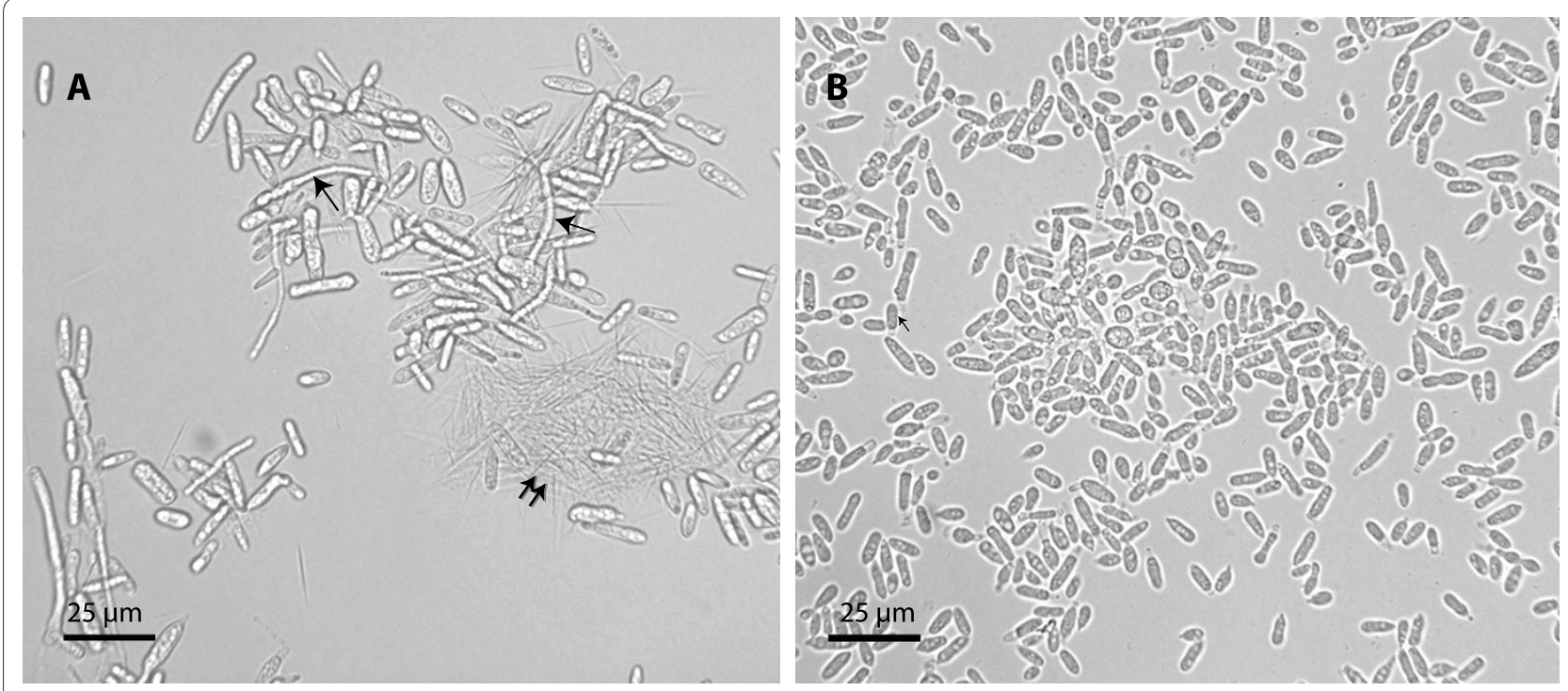

Figure 1 Microscope photographs (400x) of Pseudozyma flocculosa (cell morphology and flocculosin production) in a 120-h old culture in YMPD medium amended (A) or not (B) with sucrose after $\mathbf{7 2} \mathbf{h}$. Single arrows indicate elongating sporidia producing flocculosin; double-arrows indicate typical needle-shape crystals of flocculosin. 
tion, Madison WI, USA). Liquid chromatography (LC)tandem MS was conducted at the Genome Quebec Innovation Centre of McGill University (Montréal QC, Canada), using a Q-time-of-flight (TOF) micro MS apparatus (Waters, Milford MA, USA) and a Nanosource modified with a nanospray adapter (New Objective, Woburn MA, USA) to hold a PicoFrit column (BioBasic C18 packing, 5 $\mu \mathrm{m}, 300 \AA$ ). The inferred peptides were searched against genomic data of the newly sequenced $P$. flocculosa database using the Basic Local Alignment Search Tool (BLAST) and the CLC Genomics Workbench software, v. 3.6.1 (CLC Bio USA, Cambridge MA, USA). Homologues to the predicted ORFs were searched in the National Center for Biotechnology Information (NCBI) database and the Ustilago maydis database of the Broad Institute http://www.broadinstitute.org/annotation/genome/

ustilago maydis/Home.html. Matched sequences in these databases were further analyzed against the P. flocculosa genome to ascertain that they referred back to the predicted ORFs.

\section{Results}

\section{Culture conditions}

Protein extracts from $P$. flocculosa cells grown under two culture conditions were used for comparative purposes. Under control conditions, the conidial cells (sporidia) divided and maintained a yeast-like morphology without producing flocculosin (Fig. 1a). Under stress conditions, sporidia and mycelial fragments started elongating (pseudohyphal growth), a condition leading to flocculosin production as evidenced by the presence of needlelike crystals (Fig. 1b).

\section{Protein extraction and 2-DE}

Total proteins were isolated from the cells of each culture and resolved by 2-DE (three 2-DE replicate gels for each condition) using IEF along a linear $\mathrm{pH}$ 3-10 gradient, followed by SDS-PAGE to resolve the proteins according to their molecular mass. In brief, a comparative analysis of the 2-D gels revealed striking qualitative and quantitative differences in protein levels between the two treatments. A large number of protein spots (771) were detected in protein extracts of the control treatment compared to only 435 matched protein spots in extracts of the stress conditions, which clearly suggests an important metabolic reorganization in germinating cells producing flocculosin. A number of spots were selected for identification to further characterize the proteome of $P$. flocculosa actively producing flocculosin. Twenty protein spots specific to [or up-regulated in] the flocculosin-producing treatment were first selected based on their unique presence in the stress treatment, or based on an important increase ( $=2$-fold, significant at $P=0.05$ ) compared to control cells (Fig. 2). Ten additional spots were selected from control cells, based on criteria of uniqueness and high relative abundance (Fig. 2 and Fig. 3).

\section{Protein identification}

Of the 30 spots selected and partially sequenced by LCMS/MS (Table 1), 21 corresponded perfectly to a sequence within a predicted ORF of $P$. flocculosa. For all these 21 proteins, all short peptide sequences within the same protein used for analysis were consistently and uniquely associated with the same predicted ORF. In the case of the nine [9] unmatched proteins, the MS/MS data failed to generate the accurate peptidic sequences (nonsignificant score). Attempts to match those sequences in the $P$. flocculosa genome were unsuccessful.

When the full sequences of the 21 identified P. flocculosa ORFs were analyzed against the $U$. maydis and NCBI databanks, they all corresponded with the highest score to an annotated protein of $U$. maydis (Table 1). A reverse comparison of the 21 matching $U$. maydis proteins against the $P$. flocculosa genome confirmed the specific and unique association of these proteins with the respective ORF used for the initial analysis.

In all instances, the expression pattern of the identified proteins in P. flocculosa was fairly constant from one experiment to the next (Fig. 3). In general, our identifications revealed that most proteins induced de novo or upregulated in the stress treatment were part of carbon (e.g. thiamine biosynthesis, transketolase), fatty acid (e.g. electron transfer flavoprotein) and biogenesis (e.g. Ras-like, septin) metabolic pathways. By comparison, proteins specific to [or more abundant in] control cells (e.g. elongation factor alpha, ornithine aminotransferase) were associated essentially with primary metabolic functions such as protein biosynthesis and amino acid metabolism. Spots F28 and F29 that were specific to the control treatment, were identified as being the same protein (phosphoglycerate kinase) in spite of their distinct migration behaviour (Fig. 2).

\section{Discussion}

In this work, we have generated a first proteomic map of Pseudozyma flocculosa, a biocontrol fungus known for its antagonistic activity against powdery mildew fungi mediated, at least in part, by the release of an antifungal glycolipid, flocculosin. Our aim was to compare the proteomic profile of cell extracts grown under two specific morphological conditions, including one conducive to flocculosin synthesis, in order to gain a better understanding of the factors that could trigger the biocontrol activity of $P$. flocculosa.

Our results highlighted important qualitative and quantitative changes in the synthesis of individual proteins during the fungus' adaptation to a carbon-supplemented medium leading to flocculosin synthesis. As a 
Table 1: Comparative analysis of proteins regulated in a control culture medium or in a stress medium inducing flocculosin synthesis in Pseudozyma flocculosa cells.

\begin{tabular}{|c|c|c|c|c|c|}
\hline Spot & Protein name & $\begin{array}{l}\text { GenBank accession } \\
\text { number }\end{array}$ & Mascot Score & $\begin{array}{l}\text { Organism homology and } \\
\text { respective GenBank } \\
\text { accession number }\end{array}$ & $\begin{array}{l}\text { Peptides sequences } \\
\text { (LC MS/MS) }\end{array}$ \\
\hline \multicolumn{6}{|c|}{ Proteins specific to the stress treatment } \\
\hline F33 & $\begin{array}{l}\text { Thiamine } \\
\text { biosynthesis }\end{array}$ & GQ922830 & 258 & $\begin{array}{l}\text { Ustilago maydis } \\
71004594\end{array}$ & $\begin{array}{l}\text { K.VALLEPNDPSDVTEIIGSGK } \\
. V(2+) \\
\text { K.IGYVGEFGK.I (2+) }\end{array}$ \\
\hline F5 & $\begin{array}{l}\text { Glutamate } \\
\text { synthase }\end{array}$ & GQ922824 & 255 & $\begin{array}{l}\text { Ustilago maydis } \\
71019533\end{array}$ & $\begin{array}{l}\text { K.GKDVIVIGGGDTGCDAQA } \\
\text { TALR.H (3+) } \\
\text { R.LLMTNNFPEFTGR.V (2+) } \\
\text { R.EADGVHFAMDFLAPNTK. } \\
\text { S (3+) } \\
\text { R.EYCISTTSFEK.D (2+) } \\
\text { R.IGGLLMYGIPNMK.L (2+) }\end{array}$ \\
\hline F8 & $\begin{array}{l}\text { Aspartic acid } \\
\text { protease }\end{array}$ & 157418069 & 96 & $\begin{array}{l}\text { Pseudozyma flocculosa } \\
157418069\end{array}$ & $\begin{array}{l}\text { K.GTVYTDALTIGGLTASR.V } \\
(2+) \\
\text { K.LNAGVFQFTLAK.T }(2+)\end{array}$ \\
\hline F11 & $\begin{array}{l}24 \mathrm{kDa} \text { RAS-like } \\
\text { protein }\end{array}$ & $\underline{\text { GQ922825 }}$ & 78 & $\begin{array}{l}\text { Ustilago maydis } \\
71004934\end{array}$ & $\begin{array}{l}\text { R.NSFDEISTFHQQILR.V (3+) } \\
\text { R.INVDEAFSNLVR.E (2+) }\end{array}$ \\
\hline \multicolumn{6}{|c|}{ Proteins up-regulated in the stress treatment } \\
\hline F23 & Cyanate lyase & $\underline{\text { GQ922826 }}$ & 111 & $\begin{array}{l}\text { Ustilago maydis } \\
71007509\end{array}$ & $\begin{array}{l}\text { R.LYEVLVVYGYPLK.H (2+) } \\
\text { R.DPVLYR.L }(2+)\end{array}$ \\
\hline F46 & Transketolase & $\underline{\text { GQ922827 }}$ & 84 & $\begin{array}{l}\text { Ustilago maydis } \\
39968757\end{array}$ & $\begin{array}{l}\text { K.IEAAIPELVGGSADLTGSN } \\
\text { LTR.W (3+) }\end{array}$ \\
\hline F24 & $\begin{array}{l}\text { Electron transfer } \\
\text { flavoprotein beta } \\
\text { subunit }\end{array}$ & $\underline{\mathrm{GQ} 922828}$ & 201 & $\begin{array}{l}\text { Ustilago maydis } \\
71004000\end{array}$ & $\begin{array}{l}\text { K.FSMNPFDEIAVEEAVR.L } \\
(2+)\end{array}$ \\
\hline F42 & $\begin{array}{l}\text { Triosephosphate } \\
\text { isomerase }\end{array}$ & $\underline{\text { GQ922829 }}$ & 75 & $\begin{array}{l}\text { Ustilago maydis } \\
164661864\end{array}$ & $\begin{array}{l}\text { K.VATAEQAQEVHAAIR.Q } \\
(3+)\end{array}$ \\
\hline F39 & Transaldolase & GQ922831 & 268 & $\begin{array}{l}\text { Ustilago maydis } \\
71020109\end{array}$ & $\begin{array}{l}\text { K.IASTWEGIQAAR.E }(2+) \\
\text { K.LAEGIAGFAK.D }(2+) \\
\text { K.TIVMGASFR.N }(2+)\end{array}$ \\
\hline $\mathrm{F} 40$ & $\begin{array}{l}\text { Heat shock } \\
\text { protein of HSP70 } \\
\text { family }\end{array}$ & GQ922832 & 286 & $\begin{array}{l}\text { Ustilago maydis } \\
71020701\end{array}$ & $\begin{array}{l}\text { R.LLGEFELTGIPPQPR.G (3+) } \\
\text { R.VFTTVEDNQTQVTFPVYE } \\
\text { GER.T (3+) } \\
\text { R.KANITITNSVGR.L (3+) } \\
\text { K.ANITITNSVGR.L (2+) }\end{array}$ \\
\hline F27 & $\begin{array}{l}\text { Heat-shock } \\
\text { protein } 90^{*}\end{array}$ & $\underline{\mathrm{GQ} 922823}$ & 177 & $\begin{array}{l}\text { Cryptococcus } \\
\text { neoformans } \\
25990448\end{array}$ & $\begin{array}{l}\text { K.GIVDSEDLPLNISR.E (2+) } \\
\text { R.ELISNASDALDK.I }(2+)\end{array}$ \\
\hline F37 & $\begin{array}{l}\text { ATP synthase beta } \\
\text { chain }\end{array}$ & $\underline{\mathrm{GQ} 922833}$ & 905 & $\begin{array}{l}\text { Ustilago maydis } \\
71018215\end{array}$ & $\begin{array}{l}\text { R.IMNVIGEPMDER.G }(2+) \\
\text { R.FTQAGSETSALLGR.I }(3+) \\
\text { K.TVLIQELINNVAK.A }(2+) \\
\text { K.VALVFGQMNEPPGAR.A(3 } \\
+ \text { ) }\end{array}$ \\
\hline F25 & Septin-8 & GQ922834 & 180 & $\begin{array}{l}\text { Ustilago maydis } \\
71019031\end{array}$ & $\begin{array}{l}\text { K.LTVIDTPGFGDYVNNR.D } \\
(2+) \\
\text { K.AGGHFTLMVVGESGVGK. } \\
\text { T (3+) } \\
\text { K.TVEIDIIK.A (2+) }\end{array}$ \\
\hline
\end{tabular}


Table 1: Comparative analysis of proteins regulated in a control culture medium or in a stress medium inducing flocculosin synthesis in Pseudozyma flocculosa cells. (Continued)

\begin{tabular}{|c|c|c|c|c|c|}
\hline F26 & $\begin{array}{l}\text { Succinate } \\
\text { dehydrogenase } \\
\text { [ubiquinone] } \\
\text { flavoprotein } \\
\text { subunit }\end{array}$ & $\underline{\mathrm{GQ9}} 22835$ & 232 & $\begin{array}{l}\text { Ustilago maydis } \\
71005306\end{array}$ & $\begin{array}{l}\text { R.LGANSLLDIVVFGR.A (2+) } \\
\text { R.TVIELEHFGLPFSR.T (3+) } \\
\text { R.VMQSDAAVFR.T }(2+)\end{array}$ \\
\hline F43 & $\begin{array}{l}\text { Alphaglucosidase } \\
\text { precursor }\end{array}$ & $\underline{\text { GQ922836 }}$ & 116 & $\begin{array}{l}\text { Ustilago maydis } \\
71016306\end{array}$ & $\begin{array}{l}\text { R.RDPDETLQPFFTLDAGTP } \\
\text { VDSNMYGYHPVYTEAR.R } \\
(3+) \\
\text { R.RGLIQYR.A }(2+)\end{array}$ \\
\hline \multicolumn{6}{|c|}{ Proteins absent in the stress treatment } \\
\hline F14 & $\begin{array}{l}\text { Elongation factor } \\
\text { 1-alpha }\end{array}$ & $\underline{\text { GQ922837 }}$ & 304 & $\begin{array}{l}\text { Ustilago maydis } \\
71004810\end{array}$ & $\begin{array}{l}\text { K.IGGIGTVPVGR.V }(2+) \\
\text { K.STTTGHLIYK.C }(2+) \\
\text { R.EHALLAFTLGVR.Q 2(+) } \\
\text { K.YYVTVIDAPGHR.D } 3(+) \\
\text { K.SVEMHHEQLPEGLPGDNV } \\
\text { GFNVK.N (3+) }\end{array}$ \\
\hline F17 & $\begin{array}{l}\text { Ornithine amino- } \\
\text { transferase }\end{array}$ & $\underline{\text { GQ922838 }}$ & 132 & $\begin{array}{l}\text { Ustilago maydis } \\
71018171\end{array}$ & $\begin{array}{l}\text { K.GLLAKPTHVNIIR.L (3+) } \\
\text { R.TGFGPFLDR.V (2+) }\end{array}$ \\
\hline F18 & $\begin{array}{l}\text { 6-phospho- } \\
\text { gluconate } \\
\text { dehydrogenase }\end{array}$ & $\underline{\text { GQ922839 }}$ & 99 & $\begin{array}{l}\text { Ustilago maydis } \\
71014537\end{array}$ & $\begin{array}{l}\text { K.GILFVGSGVSGGEEGAR.H } \\
(2+) \\
\text { K.IVSYAQGFMLMR.E }(2+)\end{array}$ \\
\hline \multicolumn{6}{|c|}{ Proteins down-regulated in the stress treatment } \\
\hline F28 & $\begin{array}{l}\text { Phospho- } \\
\text { glycerate kinase }\end{array}$ & $\underline{\text { GQ922840 }}$ & 280 & $\begin{array}{l}\text { Ustilago maydis } \\
71021575\end{array}$ & $\begin{array}{l}\text { K.IQLIDNMLDK.V }(2+) \\
\text { K.YSLKPVAAEVSK.L }(2+) \\
\text { K.VNSLIICGGMAFTFK.K } \\
(3+) \\
\text { K.ALESPERPFLAILGGAK.V } \\
(3+)\end{array}$ \\
\hline F29 & $\begin{array}{l}\text { Phospho- } \\
\text { glycerate kinase }\end{array}$ & $\underline{\text { GQ922840 }}$ & 62 & $\begin{array}{l}\text { Ustilago maydis } \\
71021575\end{array}$ & $\begin{array}{l}\text { K.ALESPERPFLAILGGAK.V } \\
(2+) \\
\text { K.VNSLIICGGMAFTFK.K } \\
(2+) \\
\text { K.IQLIDNMLDK.V }(2+)\end{array}$ \\
\hline F30 & $\begin{array}{l}\text { Glucose-6- } \\
\text { phosphate 1- } \\
\text { dehydrogenase }\end{array}$ & GQ922841 & 293 & $\begin{array}{l}\text { Ustilago maydis } \\
71021693\end{array}$ & $\begin{array}{l}\text { K.LVDNVQITFK.E }(2+) \\
\text { K.SFSAEDIRDEK.V }(2+) \\
\text { K.DVTSGIFKDIPR.N }(2+)\end{array}$ \\
\hline
\end{tabular}

*Similarity was found in the MIPS Ustilago maydis database http://mips.helmholtz-muenchen.de/genre/proj/ustilago

first observation, we noted a clear decrease in the total number of proteins in the stressed cells, compared to control cells. This is indicative of an important reduction in certain metabolic activities that would be linked with the release of stress metabolites, namely flocculosin. Incidentally, Mimee et al. [10] have recently proposed that flocculosin could serve both roles of niche protection and food reserve under limiting conditions. This difference in metabolic behaviour was also accompanied with a gradual transition from the yeast-like to the filamentous form (see Fig. 1), the latter only being apt to produce flocculosin. While this transition step is not accompanied by an increase in biomass, as would be expected in typical filamentous fungi such as molds, Hammami et al. [3] sug- gested that it was induced as an adaptation/protection stage to a new environment for the epiphytic fungus. In line with these observations, some proteins associated with flocculosin biosynthesis in $P$. flocculosa were detected specifically in cells producing the glycolipid. For instance, a septin-like protein was recorded exclusively in cells grown in the carbon amended medium. Septins are GTPases that form filaments in fungi and animals, and are thought to function in controlling cytokinesis and coordinating nuclear division and membrane movement $[11,12]$. Together with septin, we also detected a Ras-like protein reported to promote filamentous growth in $U$. maydis [13]. 

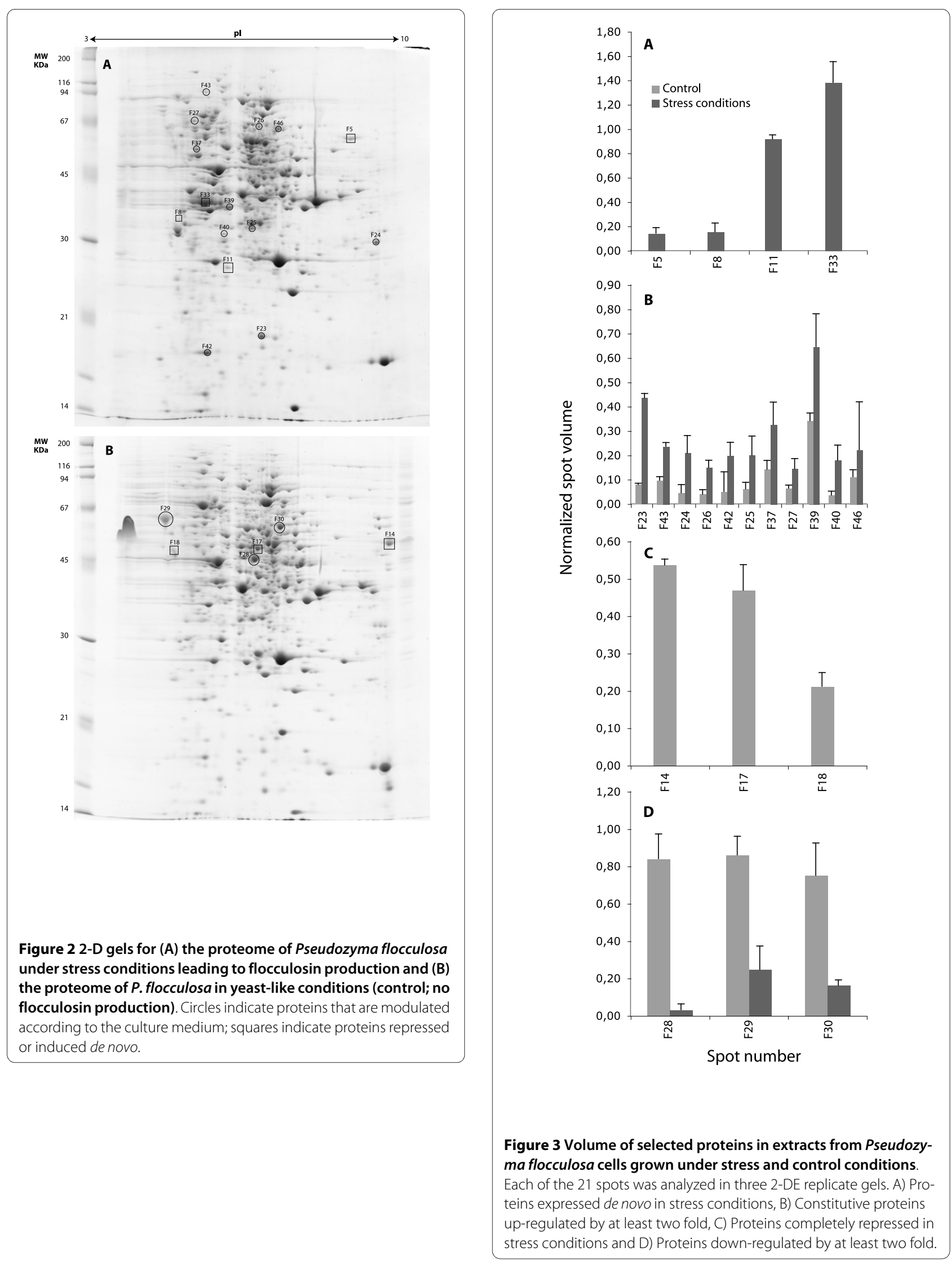
Given that flocculosin synthesis was supported by Cfed-batch, it is also normal that several protein activities found in this treatment were linked to carbon metabolism. The expression levels of transketolase and transaldolase, for instance were 2 and 2.5 fold higher, respectively in the flocculosin-inducing medium. These two enzymes are involved in the non-oxidative part of the pentose phosphate pathway. The pentose phosphate pathway involves two steps: the first one (oxidative part) metabolizes glucose-6-phosphate to ribulose-5-phosphate, the principal carbon source for nucleotide synthesis and NADPH for reductive reactions in biosynthesis and perhaps for hydroxylation [14]. When the cell is not in suitable conditions to produce biomass, ribulose-5phosphate joins the second step of the pathway (non-oxidative part), to be converted to glyceraldehyde-3-phosphate and two fructose-6-phosphate. The detection of thiamine biosynthesis activity in the flocculosin inducing medium is consistent with an increase in transketolase levels. Thiamine contributes to carbon metabolism by acting as cofactor of several enzymes such as pyruvate dehydrogenase, $\alpha$-ketoglutarate dehydrogenase, branched-chain $\alpha$-ketoacid dehydrogenase, transketolase and pyruvate decarboxylase [15]. Based on this, we can speculate that $P$. flocculosa does undergo a metabolic switch from biomass production to flocculosin production under stress conditions as proposed by Hammami $e t$ $a l$. [3]. Indeed, the latter study found that the presence of yeast extract supported the conidial biomass production of $P$. flocculosa. When growth is blocked by the exhaustion of yeast extract, flocculosin excretion might constitute an overflow metabolism for P. flocculosa that regulates the intracellular energy level.

In addition to the observation of proteins consistent with the inhibition of biomass production under stress conditions, several other proteins were induced or increased in P. flocculosa cells following the addition of a carbon source in the medium. Higher levels of glutamate synthase, cyanate lyase and heat shock protein (HSP) 70 and 90 support the hypothesis that P. flocculosa was under stress conditions following the fed-batch. The addition of carbon increases the consumption speed of the components of the complex medium YMPD including the yeast extract ingredients. The exhaustion of these components, particularly yeast extract, appears to induce flocculosin synthesis, a strategy that may have been developed by $P$. flocculosa to store excess carbon in the environment as proposed by Mimee et al. [10]. As explained earlier, the carbon backbone of flocculosin (and of ustilagic acid) is composed of a long fatty acid chain originating from palmitic acid. Here, we detected the electron transfer flavoprotein, a key cofactor of the $\beta$-oxidation which is considered a way to produce acetyl-COA in the mitochondria. Equally, the expression of pentose phosphate-related enzymes is necessary to produce $\mathrm{NADPH}$, which in turn is essential to fatty acid synthesis. Because of the complexity of the flocculosin (glycolipid) structure, its synthesis requires ATP production. Expectedly, an ATPase and other proteins such as the glycolytic enzyme, triose phosphate isomerase (TIM), succinate dehydrogenase and alpha-glucosidase involved in carbon metabolism producing the ATP molecule, were up-regulated by the carbon addition.

In the control medium, the cells tended to produce proteins that are commonly associated with biomass production. Ornithine aminotransferase has a fundamental role in the central metabolism of organisms, as it may serve for the synthesis of proline, polyamines, glutamate and glutamine. These products are of great nutritional and physiological importance for diverse functions including growth and development [16]. Also, the soluble elongation factors are likely to play an important role in limiting the error frequency during protein synthesis [17]. The low abundance of these proteins in the stress treatment suggests that carbon addition in the growth medium inhibited some activities which assure the appropriate course of cellular growth and shifted the overall metabolism toward the production of flocculosin.

Owing to the structural similarity between flocculosin and ustilagic acid, and to the phylogenetic link between $P$. flocculosa and $U$. maydis, we expected to detect in the flocculosin production treatment proteins belonging to the cluster of 12 co-regulated genes involved in ustilagic acid synthesis in $U$. maydis [18]. Our analyses did not identify any of the proteins related to this cluster of genes, whether they are present in the cytosol or in the membranes. The detection of membrane proteins such as the ATP-synthase seem to rule out the possibility that our extraction procedure failed to detect such proteins [19]. Their low relative concentration or a poor correlation between mRNA transcripts and protein accumulation for these 12 genes, as noted for many genes in yeast [6], could explain our results. A similar conclusion was reported in the study of the proteomic changes involved in the transition of $U$. maydis from budding to filamentous form [7]. Two proteins, versicolorin B synthase (UM03246) and anthranilate synthase (UM02376) that were minor components of multiprotein spots showed an increase in transcriptional level of 4- and 13-fold respectively.

Based on our observations, it does appear that P. flocculosa will only produce flocculosin early in the process of pseudohyphal formation under conditions of nutrient limitations. While this process can be artificially maintained in vitro by the addition of a $\mathrm{C}$ source, in nature it would serve as a means of protecting/forging an ecological niche as sporidia land in a new environment. This supports recent quantitative evaluation of flocculosin production in situ where Marchand et al. [4] found that 
genes involved in flocculosin synthesis were only up-regulated within the first 6 hours of sporidia coming into contact with a leaf. In the same manner, we can speculate that sporidia of $U$. maydis would produce ustilagic acid in the first steps of germination to facilitate contact with a compatible mating type, as suggested by Hewald et al. [5]

\section{Conclusion}

This work presents the first proteomic map of P. flocculosa together with a positive identification of the salient proteins. The impressive number of proteins that displayed changes in their relative rates of synthesis during the adaptation to stress conditions conveys the idea that $P$. flocculosa is an organism in which gene expression varies in response to environmental changes leading to flocculosin synthesis. This analysis was greatly validated by the recent sequencing of $P$. flocculosa genome which allowed a perfect match of the peptide sequences of 21 proteins with specific predicted ORFs in P. flocculosa. Because of the close genetic link between $U$. maydis and P. flocculosa, we were able to positively link those proteins with a known function annotated in $U$. maydis thereby confirming the high level of homology and conserved genes between the biocontrol agent and the plant pathogen.

\section{Competing interests}

The authors declare that they have no competing interests.

\section{Authors' contributions}

WH, FC and RRB have made substantial contributions to the design of the experiments, data acquisition and interpretation. WH, DM and RRB have been involved in writing the manuscript and revising it critically for content. All authors have read and approved the final manuscript.

\section{Acknowledgements}

This work was supported by grants from the Natural Sciences and Engineering Research Council of Canada (NSERC), and the Canada Research Chairs Program to R.R Bélanger. We thank Karine Coenen for her technical assistance.

\section{Author Details}

Département de Phytologie, Centre de recherche en horticulture, Université Laval, Québec G1V 0A6, Canada

Received: 16 October 2009 Accepted: 9 February 2010

Published: 9 February 2010

\section{References}

1. Clément-Mathieu G, Chain F, Marchand G, Bélanger RR: Leaf and powdery mildew colonization by glycolipid-producing Pseudozyma species. Fungal Ecology 2008, 1:69-77.

2. Mimee B, Labbé C, Pelletier R, Bélanger RR: Antifungal activity of flocculosin, a novel glycolipid isolated from Pseudozyma flocculosa. Antimicrob Agents Chemother 2005, 49:1597-1599.

3. Hammami W, Labbé C, Chain F, Mimee B, Bélanger RR: Nutritional regulation and kinetics of flocculosin synthesis by Pseudozyma flocculosa. Appl Microbiol Biotechnol 2008, 80:307-315.

4. Marchand G, Rémus-Borel W, Chain F, Hammami W, Belzile F, Bélanger RR

: New genes potentially involved in the synthesis of antimicrobial glycolipids by Pseudozyma spp. Phytopathology 2009, 99:1142-1149.

5. Hewald S, Josephs K, Bölker M: Genetic analyses of biosurfactant production in Ustilago maydis. Appl Environ Microbiol 2005, 71:3033-3040
6. Gygi SP, Rochon Y, Franza BR, Aebersold R: Correlation between protein and mRNA abundance in yeast. Mol 1999, 19:1720-1730.

7. Böhmer M, Colby T, Böhmer C, Bräutigam A, Schmidt J, Bölker M: Proteomic analysis of dimorphic transition in the phytopathogenic fungus Ustilago maydis. Proteomics 2007, 7:675-685.

8. Fernandez-Acero FJ, Jorge I, Calvo E, Vallejo I, Carbu M, Camafeita E, Lopez $J A$, Cantoral JM, Jorrin J: Two-dimensional electrophoresis protein profile of the phytopathogenic fungus Botrytis cinerea. Proteomics 2006, 6:88-96.

9. Bradford MM: A rapid and sensitive method for quantitation of microgram quantities of protein utilizing the principle of protein-dyebinding. Anal Biochem 1976, 72:48-54.

10. Mimee B, Labbé C, Bélanger RR: Catabolism of flocculosin, an antimicrobial metabolite produced by Pseudozyma flocculosa. Glycobiology 2009, 19:995-1001.

11. Kinoshita M, Noda M: Roles of septins in the mammalian cytokinesis machinery. Cell Struct Funct 2001, 26:667-670.

12. Lindsey R, Momany M: Septin localization across kingdoms: three themes with variations. Curr Opin Microbiol 2006, 9:559-565.

13. Lee $\mathrm{N}$, Kronstad W: ras 2 controls morphogenesis pheromone response and pathogenicity in the fungal pathogen Ustilago maydis. Eukaryot Cell 2002, 1:954-966.

14. Horecker BL: Yeast enzymology: retrospectives and perspectives. In New York: Biochemistry and Genetics of Yeasts. Pure and Applied Aspects Edited by: Bacila M, Horecker BL, Stoppani AOM. Academic Press Inc: 1978:1-15

15. Friedrich W: Thiamin (Vitamin B1, aneurin). Hanbuch der Vitamine, Urban \& Schwarzenberg, München, Vien, Baltimore:240-258.

16. Wagemaker MJM, Eastwood DC, Welagen J, drift C Van der, Jetten MS, Burton K, Van Griensven LJ, Op den Camp HJ: The role of ornithine aminotransferase in fruiting body formation of the mushroom Agaricus bisporus. Mycol Res 2007, 111:909-918.

17. Edelman P, Gallant J: Mistranslation in E. coli. Cell 1971, 10:131-137.

18. Teichmann B, Linne U, Hewald S, Marahiel MA, Bölker M: A biosynthetic gene cluster for a secreted cellobiose lipid with antifungal activity from Ustilago maydis. Mol Microbiol 2007, 66:525-533.

19. Mirza SP, Halligan BD, Green AS, Olivier M: Improved method for the analysis of membrane proteins by mass spectrometry. Physiol Genomics 2007, 30:89-94.

doi: 10.1186/1477-5956-8-7

Cite this article as: Hammami et al., Proteomic analysis of the metabolic adaptation of the biocontrol agent Pseudozyma flocculosa leading to glycolipid production Proteome Science 2010, 8:7

Submit your next manuscript to BioMed Central and take full advantage of:

- Convenient online submission

- Thorough peer review

- No space constraints or color figure charges

- Immediate publication on acceptance

- Inclusion in PubMed, CAS, Scopus and Google Scholar

- Research which is freely available for redistribution 